OPEN ACCESS

Edited by: Caleb Lemley,

Mississippi State University,

United States

Reviewed by:

Jessica Briffa,

The University of Melbourne, Australia

Weinan Zhou,

University of Illinois at

Urbana-Champaign, United States

*Correspondence:

Dustin T. Yates

dustin.yates@unl.edu

Specialty section

This article was submitted to Animal Physiology and Management, a section of the journal

Frontiers in Animal Science

Received: 19 August 2021

Accepted: 07 October 2021

Published: 04 November 2021

Citation:

Hicks ZM and Yates DT (2021) Going

Up Inflame: Reviewing the

Underexplored Role of Inflammatory

Programming in Stress-Induced

Intrauterine Growth Restricted

Livestock. Front. Anim. Sci. 2:761421.

doi: 10.3389/fanim.2021.761421

\section{Going Up Inflame: Reviewing the Underexplored Role of Inflammatory Programming in Stress-Induced Intrauterine Growth Restricted Livestock}

\author{
Zena M. Hicks and Dustin T. Yates* \\ Stress Physiology Laboratory, Department of Animal Science, University of Nebraska-Lincoln, Lincoln, NE, United States
}

The impact of intrauterine growth restriction (IUGR) on health in humans is well-recognized. It is the second leading cause of perinatal mortality worldwide, and it is associated with deficits in metabolism and muscle growth that increase lifelong risk for hypertension, obesity, hyperlipidemia, and type 2 diabetes. Comparatively, the barrier that IUGR imposes on livestock production is less recognized by the industry. Meat animals born with low birthweight due to IUGR are beset with greater early death loss, inefficient growth, and reduced carcass merit. These animals exhibit poor feed-to-gain ratios, less lean mass, and greater fat deposition, which increase production costs and decrease value. Ultimately, this reduces the amount of meat produced by each animal and threatens the economic sustainability of livestock industries. Intrauterine growth restriction is most commonly the result of fetal programming responses to placental insufficiency, but the exact mechanisms by which this occurs are not well-understood. In uncompromised pregnancies, inflammatory cytokines are produced at modest rates by placental and fetal tissues and play an important role in fetal development. However, unfavorable intrauterine conditions can cause cytokine activity to be excessive during critical windows of fetal development. Our recent evidence indicates that this impacts developmental programming of muscle growth and metabolism and contributes to the IUGR phenotype. In this review, we outline the role of inflammatory cytokine activity in the development of normal and IUGR phenotypes. We also highlight the contributions of sheep and other animal models in identifying mechanisms for IUGR pathologies.

\footnotetext{
Keywords: adaptive fetal programming, developmental origins of health and disease, DOHAD, fetal growth restriction, intrauterine growth restriction, IUGR, low birthweight, metabolic programming
}

\section{INTRODUCTION}

Intrauterine growth restriction (IUGR) frequently results from stress-induced placental insufficiency, which reduces $\mathrm{O}_{2}$ and nutrients available to the fetus and consequently stunts growth of the highly metabolic fetal muscle tissues (Yates et al., 2018; Pendleton et al., 2021). In livestock, low birthweight due to stress-induced IUGR causes substantial economic losses for the industry due 
to greater neonatal mortality, less metabolic efficiency, and lower carcass quality (Reynolds et al., 2010; Liu and He, 2014; Ji et al., 2017; Yates et al., 2018). Estimates put low birthweight-related losses at approximately $8 \%$ of the potential annual product for US producers and up to $20 \%$ of the global annual product ( $\mathrm{Wu}$ et al., 2006; Flinn et al., 2020). Thrifty metabolic adaptations to muscle, adipose, pancreatic islets, and other tissues cause IUGRborn offspring to be disadvantaged at birth due to insufficient energy stores and poor thermoregulation, which often results in reduced nursing success and a failure to thrive throughout the early neonatal period (Dwyer et al., 2016; Yates et al., 2018). Intrauterine growth restriction-born offspring that survive exhibit reduced feed efficiency, making it cost more to reach proper harvest weight (Bérard et al., 2008; Yates et al., 2018; Gibbs et al., 2020). Thrifty programming also manifests as reduced muscle growth capacity and increased fat deposition beginning at the juvenile age (Greenwood et al., 2000; Yates et al., 2012; Gibbs et al., 2020), which lowers carcass yield and affects meat quality parameters such as tenderness, muscle $\mathrm{pH}$, meat color, and cooking loss (Liu and He, 2014; Matyba et al., 2021). Intrauterine growth restriction also afflicts human pregnancies (Saleem et al., 2011; Nardozza et al., 2017), and global estimates indicate that upward of 53 million infants are born IUGR each year (Sedgh et al., 2014). These babies are at increased risk for perinatal morbidity and mortality (Aucott et al., 2004; Alisi et al., 2011; Alisjahbana et al., 2019) as well as for lifelong health problems such as asthma, type 2 diabetes, cardiovascular disease, obesity, and neurocognitive disorders that begin in early childhood and reduce life expectancy and quality (Nardozza et al., 2017; Darendeliler, 2019; Xing et al., 2020; Briana and Malamitsi-Puchner, 2021).

By the late 1950s, the scientific community had recognized that individuals with metabolic diseases often exhibited physiological indicators of metabolic dysfunction by the time they were neonates (Neel, 1962). However, it was the work of Hales and Barker in the early 1990s and the subsequent publication of their Thrifty Phenotype hypothesis that popularized the idea of a link between fetal developmental programming and lifelong metabolic health (Hales et al., 1991; Hales and Barker, 1992). In the almost three decades since, a number of studies in humans and animal models have advanced this theory with details of how stress before birth causes tissuespecific adaptive programming of growth and metabolism (Morrison, 2008; Posont et al., 2017; Yates et al., 2018; Posont and Yates, 2019; Pendleton et al., 2021). These nutrient-sparing fetal adaptations help to increase the chances for survival in utero but also create permanent metabolic changes that are detrimental to long-term health of the offspring (Sharma et al., 2016a; Kesavan and Devaskar, 2019; Posont and Yates, 2019). Identifying the exact mechanistic facilitators of these changes has been challenging, but one likely potential mechanism that has recently come to light is inflammatory programming (Posont et al., 2018, 2021; Cadaret et al., 2019). This review highlights findings that provide insight for how fetal stress leads to programmed changes in inflammatory pathways that regulate growth and metabolism, with a primary focus on the implications for meat animals.

\section{CAUSES AND PROGRESSION OF IUGR IUGR Is the Developmental Response to Maternofetal Stress}

Clinically, IUGR [alternatively, fetal growth restriction (Nardozza et al., 2017)] is characterized by less growth of the fetus or fetal tissues relative to expected growth potential (Sharma et al., 2016b; Reynolds et al., 2019). It is a pathological condition brought on by fetal nutrient restriction or other stress, although genetic abnormalities can increase the risk (Sharma et al., 2017). In the field of developmental origins of health and disease (DOHaD), IUGR is often used to describe the broader pathological phenotype resulting from chronic fetal stress, which typically (but not always) includes measurable reductions in placental function and birthweight (Sharma et al., 2016b). A number of different maternal conditions can result in placental stunting when they coincide with critical windows for placental growth and development (Sharma et al., 2016b; Yates et al., 2018). In livestock, common factors include environmental stress, illness or forage toxicity, nutritional imbalances, young age of the dam, uterine trauma from previous pregnancies, twin/triplet pregnancies, and side effects from artificial insemination or embryo transfer (Greenwood and Bell, 2003; Greenwood and Cafe, 2007). Such stressors redirect maternal blood flow from the gravid uterus, thus reducing nutritional support for placental hyperplasia and vasculogenesis (Burton and Jauniaux, 2018). Placental functional capacity is determined in large part by the successful establishment of uteroplacental circulation via the rapid development of villous blood vessels beginning around the end of the first trimester and continuing throughout most of the second trimester (Regnault et al., 2003; Burton and Jauniaux, 2018). Indeed, it is during this critical window that the placenta is most vulnerable to insults that may lead to reduction in its vasculature, surface area, and transport proteins needed for maternal-fetal nutrient exchange (Regnault et al., 2005; Burton and Jauniaux, 2018). During such insults, placental tissues are typically characterized by unusually high levels of inflammation, oxidative stress, and apoptotic cells (Cotechini and Graham, 2015; Burton and Jauniaux, 2018).

The diminished maternofetal interface associated with placental insufficiency ultimately reduces $\mathrm{O}_{2}$ transfer to the fetus, and reductions in placental glucose and amino acid transporters likewise reduce fetal availability of these nutrients (Brown, 2014; Yates et al., 2018; Beede et al., 2019). Indeed, fetal hypoxemia and hypoglycemia in heat stress-induced sheep models of placental insufficiency can exceed 50\% reductions near term (Macko et al., 2016; Wai et al., 2018; Stremming et al., 2020), creating a clear need for changes in metabolic processes and growth trajectories (Lackman et al., 2001; Gagnon, 2003). The phenomenon of fetal hypoglycemia can be partially mimicked by sustained maternal undernutrition, which can decrease fetal growth despite little or no impact on the size or vascularity of the placenta (Lemley et al., 2012; Eifert et al., 2015; Edwards et al., 2020; Contreras-Correa et al., 2021). Interestingly, diminished placental transfer of amino acids due to downsizing of system $\mathrm{A}$ and $\mathrm{L}$ transporters does not necessarily manifest in reduced fetal blood concentrations (Pantham et al., 2016; Wai et al., 2018), as the IUGR fetus 
compensates by slowing its protein utilization and accretion rates (Rozance et al., 2018; Wai et al., 2018; Stremming et al., 2020).

The hypoxemic and hypoglycemic conditions resulting from placental insufficiency cause a robust hormone-driven stress response by the fetus. Low blood $\mathrm{O}_{2}$ concentration detected by $\mathrm{O}_{2}$-sensitive $\mathrm{K}^{+}$channels on the chromaffin cells of the adrenal medulla stimulates secretion of the catecholamines, norepinephrine, and epinephrine (Adams and McMillen, 2000), inducing the hallmark hypercatecholaminemia that progressively worsens over the third trimester of pregnancy. Catecholamines act as strong inhibitors of insulin secretion, which together with hypoglycemia results in a chronic state of fetal hypoinsulinemia (Chen et al., 2017; Limesand and Rozance, 2017). Fetal hypoxemia also leads to an increase in circulating inflammatory cytokines (Krajewski et al., 2014; Visentin et al., 2014), which will be discussed in detail in later sections. Additional inflammatory components such as chemokine C-C motif ligand 16 (CCL16) and acute phase protein C-reactive protein (CRP) have also been found to be increased in IUGR fetuses (Makikallio et al., 2012; Visentin et al., 2014).

\section{IUGR Impairs Growth Capacity and Metabolic Function}

In most cases, the fetus can survive unfavorable conditions created by placental insufficiency by altering the development of several growth and metabolic processes in a way that reduces nutrient demands (Gagnon, 2003). First, the combined endocrine response to low fetal blood $\mathrm{O}_{2}$ content causes a redirection of blood flow away from skeletal muscle and other less vital tissues to maintain support for the brain, liver, adrenals, and pancreas (Gagnon, 2003; Poudel et al., 2015). Indeed, greater vascular resistance can reduce blood flow to muscle-dense areas such as the hindlimb by as much as $45 \%$, which in turn reduces $\mathrm{O}_{2}$ delivery by up to $40 \%$ (Rozance et al., 2018). Secondly, hypoinsulinemia reduces glucose utilization by insulin-sensitive muscle tissues (Davis et al., 2020). Interestingly, this can lead to transient enhancement of insulin sensitivity in the early neonatal period as a compensatory response (Soto et al., 2003; Ong et al., 2004). However, this wanes relatively quickly (Mericq et al., 2005), exposing underlying impairments in insulin action (Jensen et al., 2002).

\section{Poor Skeletal Muscle Growth Leads to Asymmetric Body Composition}

The reappropriation of nutrients away from skeletal muscle in the IUGR fetus causes the development more conservative muscle growth rates that are apparent in late gestation but also persist throughout the lifetime of the animal. Indeed, IUGR fetal sheep and rats were found to have smaller cross-sectional areas for all muscle fiber types (Yates et al., 2016; Cadaret et al., 2019a), indicating that less muscle hypertrophy was occurring during gestation. Intrinsic functional deficits in muscle stem cells called myoblasts are a major underlying factor for impaired muscle growth capacity (Yates et al., 2014; Soto et al., 2017; Posont et al., 2018). In ruminants and humans, muscle hyperplasia is completed early in the third trimester, and subsequent muscle growth is the result of myofiber hypertrophy (Maier et al., 1992;
Wilson et al., 1992). Indeed, postnatal muscle growth results from the accumulation of new nuclei within muscle fibers via fusion of myoblasts, which increases capacity for fiber protein synthesis (Allen et al., 1979; Davis and Fiorotto, 2009). Some fetal myoblasts form quiescent populations between the sarcolemma and the basal lamina of muscle fibers. These latent myoblast populations are called satellite cells and can later be activated to facilitate further muscle growth (Davis and Fiorotto, 2009; Yin et al., 2013). Before fusing, myoblasts undergo several cycles of proliferation followed by terminal differentiation, both of which are rate-limiting functional steps for muscle growth (Allen et al., 1979; Allen and Boxhorn, 1989). However, myoblasts from IUGR fetal sheep and rats were found to exhibit reduced proliferation and differentiation capabilities (Yates et al., 2014; Soto et al., 2017; Posont et al., 2018; Cadaret et al., 2019a), leading to reduced muscle mass at birth and throughout postnatal life, as illustrated in Figure 1.

Offspring born with low birthweight due to IUGR initially continue to exhibit slower postnatal growth. For example, lambs born IUGR due to maternal heat stress or maternofetal inflammation remained about $20 \%$ smaller at 30 days of age, with comparable reductions in average daily gain (Cadaret et al., 2019b; Yates et al., 2019; Posont et al., 2021). As IUGR-born offspring reach the juvenile stage, many begin to exhibit postnatal catch-up growth, whereby their bodyweights equalize with uncompromised herdmates. Indeed, bodyweights and average daily gain for lambs born IUGR due to maternal heat stress were reduced by only about $12 \%$ by 60 days of age (Gibbs et al., 2020), and IUGR-born beef cattle were about $8 \%$ lighter at 30 months of age (Greenwood et al., 2005; Greenwood and Cafe, 2007). However, this does not equate to recovery of muscle growth, and thus body composition remains impaired; 60-day old IUGR lambs had smaller loin eye areas, reduced muscle protein, and greater fat-to-protein ratios (Gibbs et al., 2020), and 30-month old IUGR beef cattle had smaller carcass weight, ribeye area, and longissimus muscle weight, resulting in less retail yield (Greenwood and Cafe, 2007). Estimates from these cattle indicate that each $1-\mathrm{kg}$ reduction in birthweight equated to a $4.4-\mathrm{kg}$ reduction in slaughter weight (Robinson et al., 2013; Greenwood and Bell, 2019).

\section{Nutrient-Sparing Adaptations Reduce Muscle Glucose Metabolism}

In concert with more conservative muscle growth, the IUGR fetus undergoes a glucose-sparing shift in muscle metabolism characterized by reduced oxidation and greater glycolytic lactate production. When IUGR fetal sheep were made hyperglycemic or hyperinsulinemic near term, whole-body glucose oxidation was decreased even though whole-body glucose utilization remained unchanged (Limesand et al., 2007; Brown et al., 2015). Subsequent sheep studies confirmed that the reduction in glucose oxidation rates were muscle-specific and persisted after birth (Cadaret et al., 2019b; Yates et al., 2019; Gibbs et al., 2021; Posont et al., 2021). Four-fold greater circulating lactate concentrations together with greater hepatic expression of gluconeogenic genes in IUGR fetal sheep (Brown et al., 2015) indicate that lactate produced in greater amounts by IUGR skeletal muscle supports 


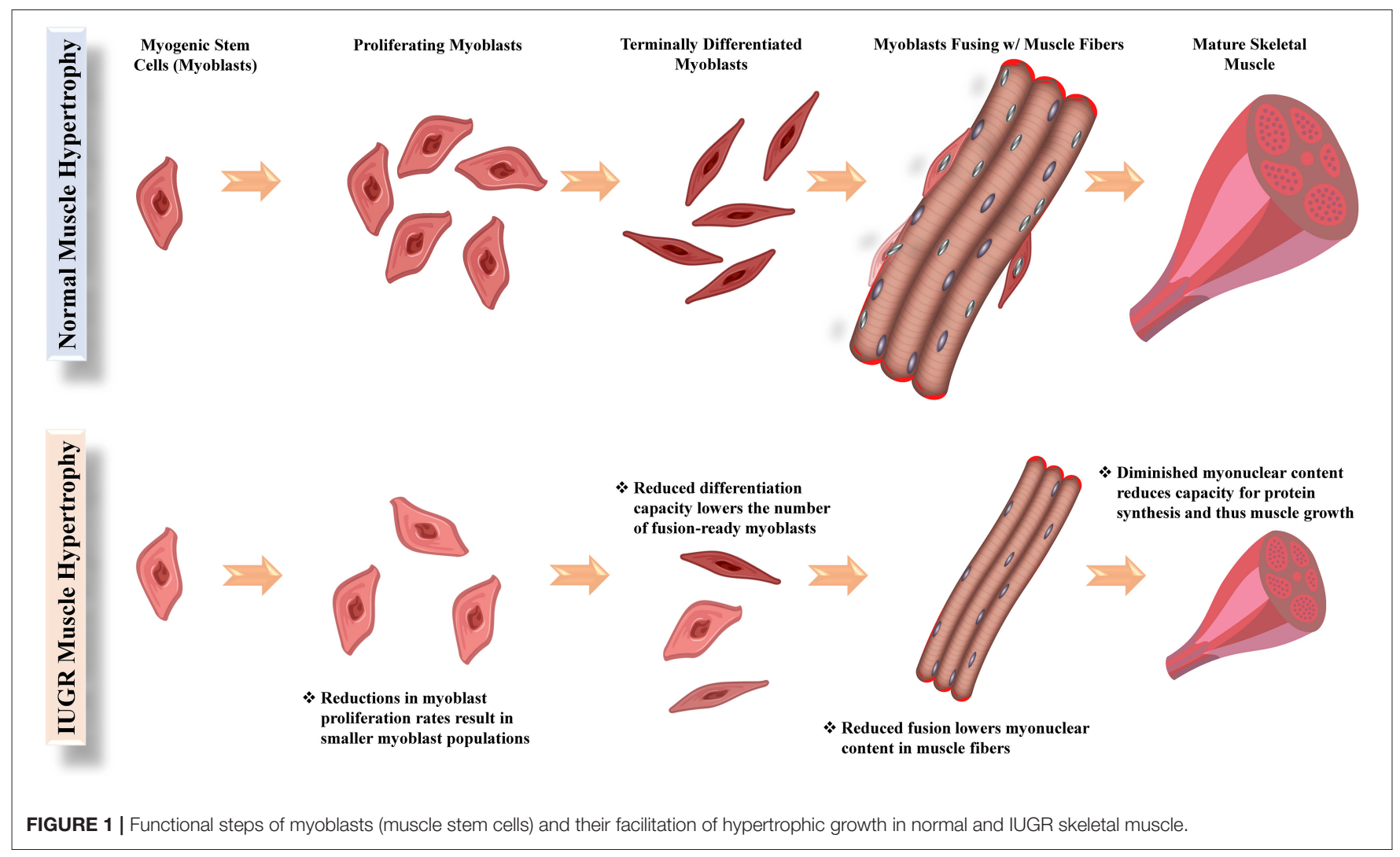

hepatic glucose production. This process, called the Cori cycle, benefits the nutrient-restricted IUGR fetus by engaging an otherwise inactive source for glucose (Thorn et al., 2009; Davis et al., 2021). However, it is important to note that the reduction in glucose oxidation arises from a programmed change in mitochondrial functional capacity that does not appear to be reversible. Although pyruvate dehydrogenase functional activity was increased in IUGR fetal sheep muscle (Pendleton et al., 2019), mitochondrial $\mathrm{O}_{2}$ consumption and electron transport chain Complex I activity were impaired (Pendleton et al., 2020). Gene expression for isocitrate dehydrogenase, mitochondrial pyruvate carrier, and other integral components of mitochondrial oxidative metabolism were also reduced in IUGR muscle, whereas gene expression for lactate dehydrogenase B (converts pyruvate to lactate) was increased 2.5-fold (Pendleton et al., 2020). It is worth noting that reduced glucose oxidation rates do not appear to be offset by compensatory amino acid oxidation (Pendleton et al., 2021). In fact, oxidation rates for the representative amino acid, leucine, were slightly reduced in IUGR fetal sheep (Brown et al., 2012; Wai et al., 2018). Moreover, impaired glucose oxidation coincided with reduced proportions of oxidative myofibers in hindlimb muscles of IUGR fetal sheep (Yates et al., 2016).

\section{Insulin Signaling Is Impaired in IUGR Skeletal Muscle} Growth and metabolic deficits in IUGR skeletal muscle are at least partially a product of disruptions in insulin signaling through Akt-mediated pathways. Insulin is a primary promotor of muscle growth, as it enhances protein synthesis (Davis and Fiorotto, 2009) and is a well-established stimulator of proliferation and differentiation in adult myoblasts (Allen et al., 1985; Sumitani et al., 2002). More recent studies found that hyperinsulinemia also increases myoblast function in fetal sheep (Brown et al., 2016b; Soto et al., 2017). Additionally, skeletal muscle is the primary tissue for insulin-mediated glucose uptake from the blood (Baron et al., 1988; Brown, 2014). This is facilitated when circulating insulin binds to receptors on the muscle fiber surface and initiates rapid mobilization of sequestered glucose transporter 4 (Glut4) to the cell membrane, where it facilitates glucose diffusion into the cell (Kubota et al., 2011). In addition to its effects on glucose uptake, insulin stimulation increased skeletal muscle glucose oxidation rates 1.5to 4-fold in fetal sheep (Brown et al., 2015; Cadaret et al., 2019) and 2- to 8-fold in growing lambs (Barnes et al., 2019; Cadaret et al., 2019b; Swanson et al., 2020; Posont et al., 2021). However, several studies have indicated that insulin/Akt signaling is impaired in IUGR muscle. Insulin activates Akt by serine ${ }^{463}$ phosphorylation, but the proportion of phosphorylated Akt was reduced in flexor digitorum superficialis muscle from IUGR fetal and neonatal sheep (Cadaret et al., 2019; Posont et al., 2021). This deficit was observed at both low and high insulin concentrations and did not coincide with any reduction in insulin receptor content (Thorn et al., 2009; Yates et al., 2019). Intrauterine growth restriction skeletal muscle also exhibited reduced content of the insulin-sensitive glucose transporter, Glut4, before and after birth (Limesand et al., 2007; Yates et al., 2019), likely due to 
TABLE 1 | Summary of the major effects that key inflammatory cytokines elicit in tissues affecting growth and efficiency in meat animals.

\begin{tabular}{|c|c|c|c|}
\hline \multirow[t]{2}{*}{ Cytokine } & \multicolumn{3}{|c|}{ Tissue } \\
\hline & Skeletal muscle & Pancreatic islets & Other \\
\hline $\mathrm{TNF} \alpha$ & $\begin{array}{l}\downarrow \text { MyoD (Li and Reid, 2001; Alvarez et al., 2020) } \\
\downarrow \text { Myoblast differentiation (Alvarez et al., 2020) } \\
\downarrow \text { Myosin, actin, and sarcoplasmic proteins (Alvarez } \\
\text { et al., 2020) } \\
\uparrow \text { Protein catabolism (Cheema et al., 2000; Popa } \\
\text { et al., 2007) } \\
\uparrow \text { Glycolysis (Boscá and Corredor, 1984; Rhoades } \\
\text { et al., 2005; Remels et al., 2015) }\end{array}$ & $\begin{array}{l}\downarrow \text { Glucose oxidation in } \beta \text { cells (Oleson et al., } \\
2015 \text { ) } \\
\downarrow \text { Glucose-stimulated insulin secretion } \\
\text { (Oleson et al., 2015) } \\
\downarrow \text { Insulin sensitivity (Youd et al., 2000; Li and } \\
\text { Reid, 2001) }\end{array}$ & $\begin{array}{l}\uparrow \text { Lipolysis in fat deposits (Cheema } \\
\text { et al., 2000; Popa et al., 2007) }\end{array}$ \\
\hline IL-6 & $\begin{array}{l}\downarrow \text { Muscle hypertrophy (Haddad et al., 2005; Bodell } \\
\text { et al., 2009) } \\
\downarrow \text { Myoblast differentiation (Haddad et al., 2005; } \\
\text { Posont et al., 2018) } \\
\uparrow \text { Muscle atrophy (Haddad et al., 2005; Bodell et al., } \\
\text { 2009) }\end{array}$ & 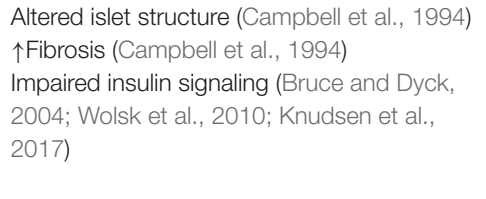 & $\begin{array}{l}\downarrow \text { GH and IGF-1 secretion and } \\
\text { sensitivity, multiple tissues (Haddad } \\
\text { et al., 2005; Bodell et al., 2009) }\end{array}$ \\
\hline IL-1 $\beta$ & $\begin{array}{l}\uparrow \text { Protein catabolism (Nawabi et al., 1990; Dinarello, } \\
\text { 2000; Li et al., 2009) } \\
\downarrow \text { Myofiber width (Li et al., 2009) } \\
\downarrow \text { Actin content (Li et al., 2009) }\end{array}$ & $\begin{array}{l}\uparrow \beta \text { cell apoptosis (Harms et al., 2015; } \\
\text { Oleson et al., 2015) } \\
\downarrow \text { Glucose-stimulated insulin secretion } \\
\text { (Harms et al., 2015; Oleson et al., 2015) }\end{array}$ & $\begin{array}{l}\text { Collagen degradation, multiple } \\
\text { tissues (Nawabi et al., 1990; } \\
\text { Dinarello, 2000; Li et al., 2009) }\end{array}$ \\
\hline
\end{tabular}

epigenetic mechanisms such as DNA methylation at the Glut4 promoter region or histone modifications (Raychaudhuri et al., 2008; Wang et al., 2016). Like insulin, the influence of IGF1 is also diminished in the IUGR fetus, as circulating IGF-1 concentrations and skeletal muscle signaling components are reduced (Thorn et al., 2009; Rozance et al., 2018).

\section{Pancreatic Islet Dysfunction Contributes to Metabolic Deficits}

Stress conditions resulting from placental insufficiency induce programming in other tissues that further compounds musclecentric dysfunction. Chief among these affected tissues are pancreatic islets, which are diminished in both development and functionality (Boehmer et al., 2017). Near term, IUGR fetal sheep islets are reduced in size by $40 \%$ (Rozance et al., 2015; Brown et al., 2016a), and $\beta$ cell mass is reduced by $60 \%$ due to a $40-60 \%$ reduction in mitosis (Limesand et al., 2005; Brown et al., 2016a). In addition to being smaller, these $\beta$ cell populations are less productive, as IUGR fetal islets contain only about $20 \%$ the amount of insulin found in normal fetal islets (Limesand et al., 2006). Deficits in islet microanatomy are preceded by insufficient islet vascular formation, which is observable shortly after the start of the third trimester (Rozance et al., 2015). Islet under-development may be due in part to less profound HGF paracrine activity originating from islet endothelial cells (Rozance et al., 2015; Brown et al., 2016a), which appears necessary for $\beta$ cell development and performance (Dai et al., 2005; Johansson et al., 2009). Like muscle, IUGR fetal islets are also less capable of glucose oxidation, which is the impetus for glucose-stimulated insulin secretion (Limesand et al., 2006). These programmed deficits persist in offspring, as islets from IUGR-born lambs maintained substantially reduced insulin content and glucose stimulus-secretion coupling (Yates et al., 2019), leading to impairments in glucose-stimulated insulin secretion that are comparable to the fetus (Cadaret et al., 2019b; Yates et al., 2019). Interestingly, $\alpha$ cell mass is reduced in IUGR fetal islets, but not to the same magnitude observed for $\beta$ cells. Moreover, their capacity to appropriately secrete glucagon appears to be unaffected (Limesand et al., 2005).

\section{THE ROLE OF INFLAMMATORY CYTOKINES IN IUGR OUTCOMES Cytokines Regulate Muscle Growth and
Metabolism}

Cytokines are a broad class of peptide chemical messengers produced by a wide array of cell and tissue types, often in response to the presence of pathogens, toxins, free radicals, and stress (Tracey and Cerami, 1993; Reid and Li, 2001). Among their other immune functions, inflammatory cytokines modify metabolic activity in muscle and other tissues in order to reappropriate $\mathrm{O}_{2}$, glucose, and protein ( $\mathrm{Li}$ and Reid, 2001; Cadaret et al., 2017). They are also potent regulators of muscle growth via their complex impact on myoblast function and insulin sensitivity (Otis et al., 2014; Posont et al., 2018). This makes the broad cytokine milieu integral to metabolic homeostasis and, in turn, general metabolic health, as summarized in Table $\mathbf{1}$.

Tumor necrosis factor $\alpha(\mathrm{TNF} \alpha)$ is perhaps the most comprehensively studied inflammatory cytokine. It is produced in greatest quantities by circulating monocytes and their intratissue counterparts, macrophages, but is also produced by glycolytic skeletal muscle fibers and fat cells (Tracey and Cerami, 1993; Li and Reid, 2001; Plomgaard et al., 2005; Dyck et al., 2006). Basal circulating TNF $\alpha$ concentrations are typically low but increase rapidly and profoundly when stimulated (Tracey and Cerami, 1993; Li and Reid, 2001). Pathological metabolic states such as excessive fat deposition, insulin resistance, 
and hyperglycemia are associated with substantially greater production and secretion of TNFa (Saghizadeh et al., 1996; Lo et al., 2007), as is pathological muscle atrophy (Li and Reid, 2001). Most cell types express one or both of two surface $\mathrm{TNF} \alpha$ receptor isoforms (TNFR1, TNFR2), and TNFR1 is predominant for muscle (Popa et al., 2007). Once activated by $\mathrm{TNF} \alpha$, the intracellular domain of TNFR1 binds and activates the downstream TNFR1-associated death domain (TRADD) proteins (Popa et al., 2007), which in turn activate Fas-associated protein with death domain (FADD) pathways and TRAF2/NFкB pathways (Popa et al., 2007). In skeletal muscle, these pathways are most associated with protein catabolism, lipolysis, and metabolic suppression (Cheema et al., 2000; Li and Reid, 2001; Popa et al., 2007). They also decrease synthesis of the myofibril components myosin and actin as well as sarcoplasmic proteins (Cheema et al., 2000; Li and Reid, 2001; Lang et al., 2002). In differentiating myoblasts, $\mathrm{TNF} \alpha$ inhibits $\mathrm{MyoD}$ expression, which impedes their progression, and in mature fibers it increases protein catabolism, which reduces the content of myosin and other integral proteins for muscle function (Li and Reid, 2001). Both of these outcomes appear to be mediated by canonical NFKB pathways (Li and Reid, 2001; Remels et al., 2015). In mature skeletal muscle, $\mathrm{TNF} \alpha$-activated $\mathrm{NF} \kappa \mathrm{B}$ pathways increase the proportion of glucose undergoing glycolytic lactate production by increasing activity of HIF-1 $\alpha$, which is concurrent with reduced glycogen synthesis (Boscá and Corredor, 1984; Rhoades et al., 2005; Remels et al., 2015). The effects of TNF $\alpha$ on glucose oxidation rates are more complex, as the cytokine appears to be stimulatory during acute exposure but inhibitory when exposure is sustained (Gao et al., 2012; Cadaret et al., 2017, 2019). In addition to direct effects on muscle growth and metabolism, $\mathrm{TNF} \alpha$ also impairs insulin sensitivity. In rats, TNF $\alpha$ diminished the effects of insulin on skeletal muscle glucose uptake by $50 \%$ (Youd et al., 2000; Li and Reid, 2001), perhaps by increasing the content of diacylglyceride, a potent activator of the insulin antagonist protein kinase C (Bruce and Dyck, 2004; Dyck et al., 2006). In pancreatic islet cells, $\mathrm{TNF} \alpha$ exposure was shown to reduce glucose metabolism in $\beta$ cells and, in turn, glucosestimulated insulin secretion (Oleson et al., 2015).

The interleukin IL-6 is produced by leukocytes and muscle cells, often in response to rising $\mathrm{TNF} \alpha$ concentrations (Tracey and Cerami, 1993; Haddad et al., 2005). Consequently, circulating IL-6 concentrations follow similar patterns as TNF $\alpha$ during sub-acute and chronic inflammatory conditions (Wolsk et al., 2010). When bound, the soluble IL-6 receptor (IL6R) forms a heterodimer with the downstream messenger gp130 (Wang et al., 2013), which primarily activates the JAK/STAT3 pathway but can also activate PI3K/Akt/mTOR and Ras/Raf/MEK/ERK pathways (Wang et al., 2013; Johnson et al., 2018). Elevated IL-6 activity limits hypertrophic muscle growth by interfering with growth hormone and IGF-I activity and also increases muscle protein catabolism, thus contributing to muscle atrophy (Haddad et al., 2005; Bodell et al., 2009). Although it may increase myoblast proliferation at some concentrations, IL-6 also reduces the progression of differentiation in primary fetal sheep myoblasts (Haddad et al., 2005; Posont et al., 2018). The predominant aspects of metabolic regulation by IL- 6 are similar to those of TNF $\alpha$. First, the nature of its effects on skeletal muscle appear dependent on the magnitude and duration of exposure, as sustained exposure is substantially more detrimental. Additionally, IL-6 is associated with pathological metabolic states, presumably due to its propensity to decrease skeletal muscle carbohydrate metabolism in favor of fatty acid oxidation and to disrupt insulin signaling (Bruce and Dyck, 2004; Wolsk et al., 2010; Knudsen et al., 2017). Finally, IL-6 is detrimental to pancreatic islet function, as overexpression of IL6 in $\beta$ cells resulted in alterations to islet structure, increased fibrosis, and decreased insulin production (Campbell et al., 1994).

Additional inflammatory cytokines appear to have roles in muscle regulation but have been less extensively studied. For example, IL-1 $\beta$ is involved in collagen degradation, muscle protein catabolism, and branched-chain amino acid metabolism (Nawabi et al., 1990; Dinarello, 2000; Li et al., 2009). Consequently, it is associated with reduced myofiber width, myofibril construction, and actin content (Li et al., 2009). In islets, IL-1 $\beta$ promotes $\beta$ cell apoptosis, which impairs glucosestimulated insulin secretion (Harms et al., 2015; Oleson et al., 2015). IL-18, IL-8, and TWEAK appear to have similar roles in regulating muscle growth and metabolism.

\section{Inflammatory Tone Is Increased in the IUGR Fetus}

Studies in a multitude of mammalian species show that IUGR fetuses exhibit greater circulating leukocyte and cytokine concentrations, which correlate closely with hypoxemia (Romero et al., 2007; Guo et al., 2010; Cadaret et al., 2019; Oh et al., 2019). Increased TNF $\alpha$, IL-6, and IL-18 were observed in cord blood of IUGR infants at delivery and in blood serum at $24 \mathrm{~h}$ after delivery (Krajewski et al., 2014; Visentin et al., 2014). In fact, high concentrations of inflammatory cytokines in cord blood are considered reliable clinical markers for diagnosing fetal inflammatory response syndrome (FIRS) (Kemp, 2014). In IUGR fetal sheep, greater circulating $\mathrm{TNF} \alpha$ in the mid-third trimester coincided with increased monocytes, granulocytes, and total white blood cells (Cadaret et al., 2019). Similarly, IUGR fetal rodents exhibited elevated blood concentrations of TNF $\alpha$, IL-6, and IFN $\gamma$, as well as greater leukocyte activity (Hudalla et al., 2018; Cadaret et al., 2019a). In addition to circulating concentrations, cytokine expression is elevated in IUGR tissues including lungs, brain, skeletal muscle, and white blood cells (Kemp, 2014; Cadaret et al., 2019a), but not necessarily in pancreatic islets (Kelly et al., 2017).

\section{IUGR Tissues Develop Enhanced Inflammatory Sensitivity}

Some rodent models of IUGR indicate that greater circulating cytokine concentrations are maintained into adulthood. Indeed, IUGR-born rat and mice offspring exhibited greater circulating TNF $\alpha$, IL-6, and IL-1 $\beta$ from birth to adulthood (Desai et al., 2009; Riddle et al., 2014; Chisaka et al., 2016; Oliveira et al., 2017). However, recent findings indicate that enhanced cytokine signaling pathways in muscle and other tissues maintain increased inflammatory tone even when elevated circulating 
cytokines subside after birth (Cadaret et al., 2019a; Posont et al., 2021). We have postulated that this enhanced responsiveness to cytokines contributes to the persistent dysregulation of muscle growth and metabolic function observed in IUGR-born offspring (Yates et al., 2018; Posont and Yates, 2019). At term, skeletal muscle from IUGR rat pups exhibited greater gene expression for TNFR1, IL6R, and Fn14 (TWEAK receptor) (Cadaret et al., 2019a). Moreover, muscle from IUGR-born mice and rats exhibited greater TNF $\alpha$ and IL- 6 gene expression at 2 and 12 months after birth (Sutton et al., 2010; Tarry-Adkins et al., 2016). In sheep, proliferation and differentiation rates of primary IUGR fetal myoblast were reduced when exposed to basal or high TNF $\alpha$ or IL-6 concentrations (Posont et al., 2018). Additional data from these samples indicate increased gene expression for TNFR1 and IL6R in IUGR myoblasts and semitendinosus muscle, as well as reduced muscle I $\mathrm{B} \alpha$ protein content and increased c-Fos protein content (Posont, 2019). As neonates, IUGR-born lambs exhibited increased TNFR1 protein content in semitendinosus muscle and greater circulating concentrations of monocytes, granulocytes, and platelets (Posont et al., 2021). Transcriptomics were subsequently performed in muscle samples from these lambs, which indicate that gene expression for numerous components of TNF $\alpha$, IL-6, IL- $1 \beta$, and IL-12 pathways were upregulated (Yates et al., 2018; Cadaret, 2019), as summarized in Figure 2. This paralleled similar transcriptomics findings in skeletal muscle from IUGR fetal sheep (Cadaret et al., 2019; Posont and Yates, 2019). Interestingly, IUGR-born lambs also exhibited greater muscle Iк $\mathrm{B} \alpha$ protein content and a $50 \%$ reduction in circulating $\mathrm{TNF} \alpha$, perhaps as a compensatory mechanism for enhanced cytokine sensitivity (Posont et al., 2021). Although additional studies are needed to fully understand the magnitude and nature of inflammatory programming in IUGR skeletal muscle, it is clear that such enhanced activity would help to explain the deficits in myoblast function, muscle growth, body composition, insulin action, and metabolic efficiency described in earlier sections.

\section{Targeting Inflammatory Adaptations May Improve IUGR Outcomes}

Inflammatory programming is likely one of several underlying mechanisms for IUGR-associated pathologies, but its ability to be targeted makes it of particular interest. In fact, several studies have provided fundamental evidence that treating IUGR fetuses and IUGR-born offspring with anti-inflammatory nutrients or pharmaceuticals can help to mitigate or improve growth and metabolic deficits. In mice, maternal supplementation of the antiinflammatory nutraceutical folic acid reduced the frequency and severity of IUGR resulting from maternal inflammation (Zhao et al., 2013). The mice receiving folic acid also exhibited a less severe increase in amniotic concentrations of IL-6 and other cytokines. Although not assessed in muscle, the enhancement of cytokine signaling pathways observed in IUGR placental tissues was mitigated by folic acid (Zhao et al., 2013). In sheep, direct daily infusion of the anti-inflammatory nutraceutical eicosapentaenoic acid (EPA) into the bloodstream of IUGR fetuses during the mid-third trimester of gestation for 5 days resulted in less severe fetal hypoxemia, hypoglycemia, and hyperlactatemia (Beer et al., 2021). In addition, the greater lactate production observed for IUGR fetuses during hyperglycemia was improved substantially, perhaps indicating a less severe metabolic shift to glycolytic lactate production by muscle (Lacey et al., 2021). This coincided with an improvement in fetal growth and body symmetry. EPA infusion also improved whole hindlimb mass as well as loin and flexor digitorum superficialis muscle mass in the IUGR fetuses, which is indicative of improved muscle growth during late gestation (Lacey et al., 2021). It is worth noting that growth was not recovered for all muscles, which may have been due to the natural differences in insulin sensitivity and metabolic phenotypes among muscle groups (Kirchofer et al., 2002). After IUGR fetuses had been infused with EPA for 5 days, they exhibited improved basal and glucose-stimulated insulin secretion, indicating partial rescue of pancreatic islet function (Lacey et al., 2021). These fetuses also exhibited improvements in blood $\mathrm{pH}, \mathrm{HCO}_{3}, \mathrm{Na}^{+}$, and $\mathrm{Ca}^{++}$concentrations, which indicate improved fetal health and well-being (Lacey et al., 2021). In addition to nutrient compounds, maternal delivery of anti-inflammatory pharmaceuticals may also represent an effective intervention strategy. A recent clinical study showed that high doses of the non-steroidal anti-inflammatory drug (NSAID) aspirin taken by pregnant women during critical windows of fetal development reduced the frequency of IUGR (Roberge et al., 2017). Of course, the benefits of such drugs must be considered in combination with potential side effects for fetal development. Inflammatory programming can also be targeted in offspring, which is of particular interest in livestock. Dietary supplementation of the anti-inflammatory nutraceutical curcumin to IUGR-born neonatal pigs and mice mitigated the elevated concentrations of blood TNF $\alpha$, IL-6, and IL-1 $\beta$, which improved insulin sensitivity, lipid homeostasis, and neonatal growth (Niu et al., 2019a,b,c).

\section{IMPLICATIONS}

The link between maternofetal stress, IUGR-induced low birthweight, and postnatal deficits in metabolic efficiency and growth potential are well-established in livestock, but scientific advancements regarding the molecular mechanisms underlying this link have been lacking. However, recent studies provide evidence that systemic fetal inflammation and developmental programming that enhances tissue sensitivity to inflammatory cytokines are contributing factors to growth and metabolic deficits, particularly those that are muscle centric. Although inflammatory programming is likely one of many underlying mechanisms, it is of particular interest to the livestock industry because it is both identifiable and treatable. Indeed, there are a number of currently marketed nutritional supplements and pharmaceuticals with anti-inflammatory properties, which could provide producers a number of options for mitigation and treatment strategies. Food animals born with low birthweight due to stress-induced IUGR are persistently one of the greatest barriers to US and global livestock production. Moreover, the emergence of climate change will likely increase the 


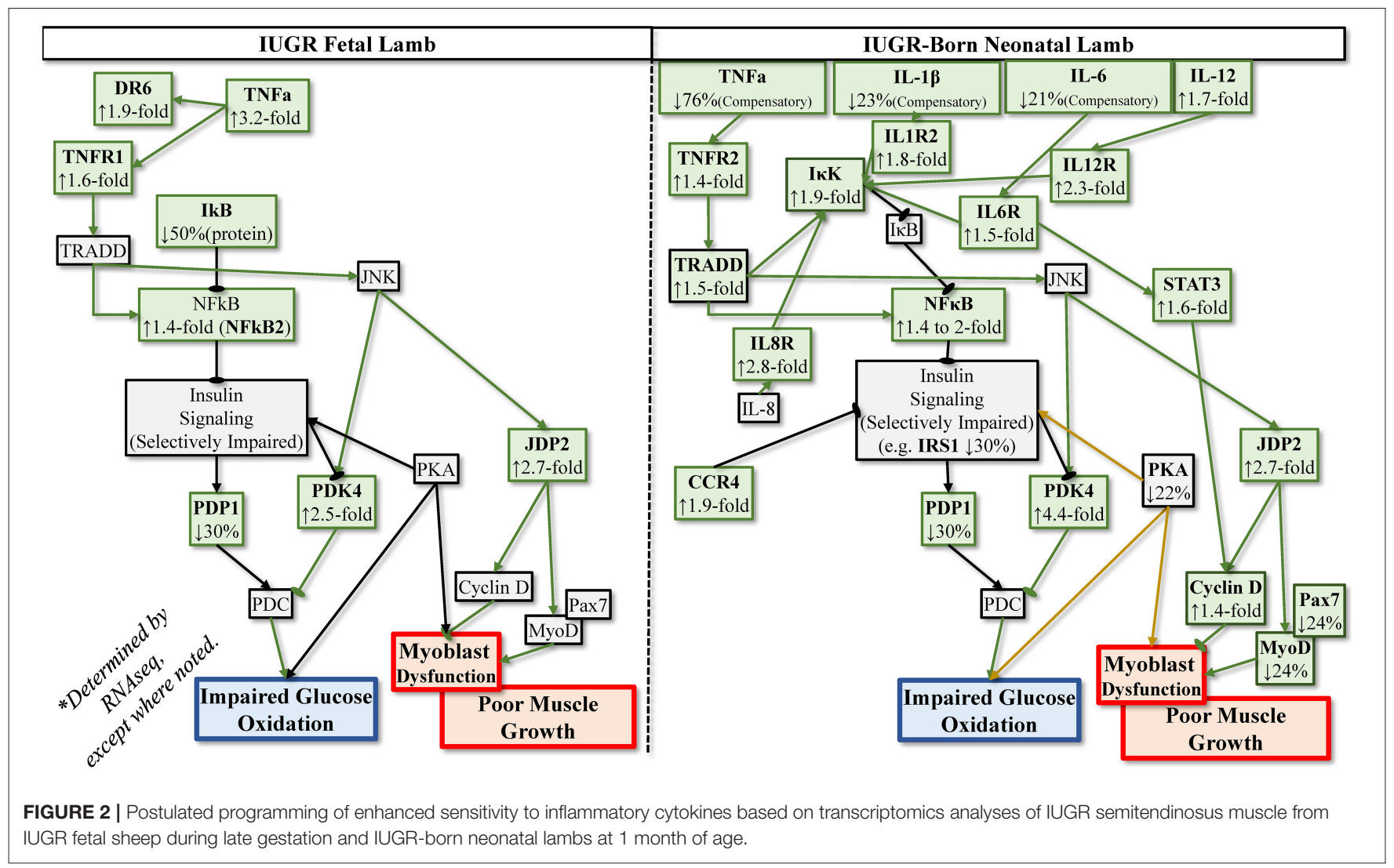

incidence of environmental stress on pregnant animals, creating a greater challenge for sustainable livestock production. As the global population continues to increase, recovering growth, efficiency, and meat production in low birthweight animals through practical management strategies represents one of the most realistic options for increasing meat production without greater land and water resource inputs. Although more work is warranted, early evidence indicates that treatment of enhanced inflammatory tone in IUGR-born animals may be an effective approach.

\section{AUTHOR CONTRIBUTIONS}

All authors listed have made a substantial, direct and intellectual contribution to the work, and approved it for publication.

\section{REFERENCES}

Adams, M. B., and McMillen, I. C. (2000). Actions of hypoxia on catecholamine synthetic enzyme mRNA expression before and after development of adrenal innervation in the sheep fetus. J. Physiol. 529, 519-531. doi: 10.1111/j.1469-7793.2000.00519.x

Alisi, A., Panera, N., Agostoni, C., and Nobili, V. (2011). Intrauterine growth retardation and nonalcoholic fatty liver disease in children. Int. J. Endocrinol. 2011, 269853. doi: 10.1155/2011/269853

Alisjahbana, B., Rivami, D. S., Octavia, L., Susilawati, N., Pangaribuan, M., Alisjahbana, A., et al. (2019). Intrauterine growth retardation (IUGR)

\section{FUNDING}

Work for this manuscript was supported in part by the USDA National Institute of Food and Agriculture Foundational Grants 2019-67015-29448 and 2020-67015-30825, the National Institute of General Medical Sciences Grant 1P20GM104320 (J. Zempleni, Director), the Nebraska Agricultural Experiment Station with funding from the Hatch Act (accession number 1009410), and Hatch Multistate Research capacity funding program (accession numbers 1011055, 1009410) through the USDA National Institute of Food and Agriculture. The Biomedical and Obesity Research Core (BORC) in the Nebraska Center for Prevention of Obesity Diseases (NPOD) receives partial support from NIH (NIGMS) COBRE IDeA award NIH 1P20GM104320.

as determinant and environment as modulator of infant mortality and morbidity: the Tanjungsari Cohort Study in Indonesia. Asia Pac. J. Clin. Nutr. 28(Suppl 1), S17-S31. doi: 10.6133/apjcn.201901_28(S1). 0002

Allen, R. E., and Boxhorn, L. K. (1989). Regulation of skeletal muscle satellite cell proliferation and differentiation by transforming growth factor-beta, insulinlike growth factor I, and fibroblast growth factor. J. Cell. Physiol. 138, 311-315. doi: $10.1002 /$ jcp.1041380213

Allen, R. E., Luiten, L. S., and Dodson, M. V. (1985). Effect of insulin and linoleic acid on satellite cell differentiation. J. Anim. Sci. 60, 1571-1579. doi: $10.2527 /$ jas1985.6061571x 
Allen, R. E., Merkel, R. A., and Young, R. B. (1979). Cellular aspects of muscle growth - myogenic cell-proliferation. J. Anim. Sci. 49, 115-127. doi: $10.2527 /$ jas $1979.491115 \mathrm{x}$

Alvarez, A. M., DeOcesano-Pereira, C., Teixeira, C., and Moreira, V. (2020). IL$1 \beta$ and TNF- $\alpha$ modulation of proliferated and committed myoblasts: IL- 6 and COX-2-derived prostaglandins as key actors in the mechanisms involved. Cells 9, 2005. doi: 10.3390/cells9092005

Aucott, S. W., Donohue, P. K., and Northington, F. J. (2004). Increased morbidity in severe early intrauterine growth restriction. J. Perinatol. 24, 435-440. doi: 10.1038/sj.jp.7211116

Barnes, T. L., Cadaret, C. N., Beede, K. A., Schmidt, T. B., Petersen, J. L., and Yates, D. T. (2019). Hypertrophic muscle growth and metabolic efficiency were impaired by chronic heat stress, improved by zilpaterol supplementation, and not affected by ractopamine supplementation in feedlot lambs. J. Anim. Sci. 97, 4101-4113. doi: 10.1093/jas/skz271

Baron, A. D., Brechtel, G., Wallace, P., and Edelman, S. V. (1988). Rates and tissue sites of non-insulin- and insulin-mediated glucose uptake in humans. Am. J. Physiol. 255(6 Pt 1), E769-E774. doi: 10.1152/ajpendo.1988.255.6.E769

Beede, K. A., Limesand, S. W., Petersen, J. L., and Yates, D. T. (2019). Real supermodels wear wool: summarizing the impact of the pregnant sheep as an animal model for adaptive fetal programming. Anim. Front. 9, 34-43, doi: 10.1093/af/vfz018

Beer, H. N., Lacey, T. A., Gibbs, R. L., Most, M. S., Hicks, Z. H., Grijalva, P. C., Petersen, J. L., and Yates, D. T. (2021). Placental insufficiency improves in intrauterine growth-restricted fetal sheep receiving daily $\omega-3$ fatty acid infusions. Transl. Anim. Sci. 5(4 Suppl 1). doi: 10.1093/tas/txab166

Bérard, J., Kreuzer, M., and Bee, G. (2008). Effect of litter size and birth weight on growth, carcass and pork quality, and their relationship to postmortem proteolysis. J. Anim. Sci. 86, 2357-2368. doi: 10.2527/jas.2008-0893

Bodell, P. W., Kodesh, E., Haddad, F., Zaldivar, F. P., Cooper, D. M., and Adams, G. R. (2009). Skeletal muscle growth in young rats is inhibited by chronic exposure to IL- 6 but preserved by concurrent voluntary endurance exercise. J. Appl. Physiol. (1985). 106, 443-453. doi: 10.1152/japplphysiol.90831.2008

Boehmer, B. H., Limesand, S. W., and Rozance, P. J. (2017). The impact of IUGR on pancreatic islet development and beta-cell function. J. Endocrinol. 235, R63-R76. doi: 10.1530/JOE-17-0076

Boscá, L., and Corredor, C. (1984). Is phosphofructokinase the ratelimiting step of glycolysis? Trends Biochem. Sci. 9, 372-373. doi: 10.1016/0968-0004(84)90214-7

Briana, D. D., and Malamitsi-Puchner, A. (2021). Intrauterine growth restriction: the controversial role of perinatal adipocytokines in the prediction of metabolic adult disease. J. Matern. Fetal Neonatal Med. 34, 2577-2582. doi: 10.1080/14767058.2019.1669556

Brown, L. D. (2014). Endocrine regulation of fetal skeletal muscle growth: impact on future metabolic health. J. Endocrinol. 221, R13-R29. doi: 10.1530/JOE-13-0567

Brown, L. D., Davis, M., Wai, S., Wesolowski, S. R., Hay, W. W. Jr., Limesand, S. W., et al. (2016a). Chronically increased amino acids improve insulin secretion, pancreatic vascularity, and islet size in growth-restricted fetal sheep. Endocrinology 157, 3788-3799. doi: 10.1210/en.2016-1328

Brown, L. D., Rozance, P. J., Bruce, J. L., Friedman, J. E., Hay, W. W. Jr., and Wesolowski, S. R. (2015). Limited capacity for glucose oxidation in fetal sheep with intrauterine growth restriction. Am. J. Physiol. Regul. Integr. Comp. Physiol. 309, R920-R928. doi: 10.1152/ajpregu.00197.2015

Brown, L. D., Rozance, P. J., Thorn, S. R., Friedman, J. E., and Hay, W. W. Jr. (2012). Acute supplementation of amino acids increases net protein accretion in IUGR fetal sheep. Am. J. Physiol. Endocrinol. Metab. 303, E352-E364. doi: 10.1152/ajpendo.00059.2012

Brown, L. D., Wesolowski, S. R., Kailey, J., Bourque, S., Wilson, A., Andrews, S. E., et al. (2016b). Chronic hyperinsulinemia increases myoblast proliferation in fetal sheep skeletal muscle. Endocrinology 157, 2447-2460. doi: 10.1210/en.2015-1744

Bruce, C. R., and Dyck, D. J. (2004). Cytokine regulation of skeletal muscle fatty acid metabolism: effect of interleukin-6 and tumor necrosis factor-alpha. Am. J. Physiol. Endocrinol. Metab. 287, E616-E621. doi: 10.1152/ajpendo.00150.2004

Burton, G. J., and Jauniaux, E. (2018). Pathophysiology of placentalderived fetal growth restriction. Am. J. Obstet. Gynecol. 218, S745-S761. doi: 10.1016/j.ajog.2017.11.577
Cadaret, C. N. (2019). Maternofetal Stress Impairs Skeletal Muscle Growth and Glucose Metabolism in the IUGR-Born Neonatal Lamb; The Effects of Varying the Cognitive Processes Required by Retrieval Practice on the Retention of Knowledge. ETD collection for University of Nebraska, Lincoln AAI27543937.

Cadaret, C. N., Beede, K. A., Riley, H. E., and Yates, D. T. (2017). Acute exposure of primary rat soleus muscle to zilpaterol $\mathrm{HCl}$ ( $\beta 2$ adrenergic agonist), TNF $\alpha$, or IL- 6 in culture increases glucose oxidation rates independent of the impact on insulin signaling or glucose uptake. Cytokine 96, 107-113. doi: 10.1016/j.cyto.2017.03.014

Cadaret, C. N., Merrick, E. M., Barnes, T. L., Beede, K. A., Posont, R. J., Petersen, J. L., et al. (2019). Sustained maternal inflammation during the early third-trimester yields intrauterine growth restriction, impaired skeletal muscle glucose metabolism, and diminished beta-cell function in fetal sheep. J. Anim. Sci. 97, 4822-4833. doi: 10.1093/jas/skz321

Cadaret, C. N., Posont, R. J., Beede, K. A., Riley, H. E., Loy, J. D., and Yates, D. T. (2019a). Maternal inflammation at midgestation impairs subsequent fetal myoblast function and skeletal muscle growth in rats, resulting in intrauterine growth restriction at term. Transl. Anim. Sci. 3, 867-876. doi: $10.1093 /$ tas/txz037

Cadaret, C. N., Posont, R. J., Swanson, R. M., Beard, J. K., Barnes, T. L., Beede, K. A., et al. (2019b). Intermittent maternofetal O2 supplementation during late gestation rescues placental insufficiency-induced intrauterine growth restriction and metabolic pathologies in the neonatal lamb. Transl. Anim. Sci. 3(Suppl 1), 1696-1700. doi: 10.1093/tas/txz060

Campbell, I. L., Hobbs, M. V., Dockter, J., Oldstone, M. B., and Allison, J. (1994). Islet inflammation and hyperplasia induced by the pancreatic islet-specific overexpression of interleukin-6 in transgenic mice. Am. J. Pathol. 145, 157-166.

Cheema, I. R., Hermann, C., Postell, S., and Barnes, P. (2000). Effect of chronic excess of tumour necrosis factor-alpha on contractile proteins in rat skeletal muscle. Cytobios 103, 169-176.

Chen, X., Kelly, A. C., Yates, D. T., Macko, A. R., Lynch, R. M., and Limesand, S. W. (2017). Islet adaptations in fetal sheep persist following chronic exposure to high norepinephrine. J. Endocrinol. 232, 285-295. doi: 10.1530/JOE16-0445

Chisaka, T., Mogi, M., Nakaoka, H., Kan-No, H., Tsukuda, K., Wang, X. L., et al. (2016). Low-protein diet-induced fetal growth restriction leads to exaggerated proliferative response to vascular injury in postnatal life. Am. J. Hypertens. 29, 54-62. doi: 10.1093/ajh/hpv072

Contreras-Correa, Z. E., Messman, R. D., Sidelinger, D. R., King, E. H., SánchezRodríguez, H. L., Burnett, D. D., et al. (2021). Melatonin alters bovine uterine artery hemodynamics, vaginal temperatures and fetal morphometrics during late gestational nutrient restriction in a season-dependent manner. J. Anim. Sci. 99, skab242. doi: 10.1093/jas/skab242

Cotechini, T., and Graham, C. H. (2015). Aberrant maternal inflammation as a cause of pregnancy complications: a potential therapeutic target? Placenta 36, 960-966. doi: 10.1016/j.placenta.2015.05.016

Dai, C., Huh, C. G., Thorgeirsson, S. S., and Liu, Y. (2005). Beta-cell-specific ablation of the hepatocyte growth factor receptor results in reduced islet size, impaired insulin secretion, and glucose intolerance. Am. J. Pathol. 167, 429-436. doi: 10.1016/S0002-9440(10)62987-2

Darendeliler, F. (2019). IUGR: genetic influences, metabolic problems, environmental associations/triggers, current and future management. Best Pract. Res. Clin. Endocrinol. Metab. 33, 101260. doi: 10.1016/j.beem.2019. 01.001

Davis, M. A., Camacho, L. E., Anderson, M. J., Steffens, N. R., Pendleton, A. L., Kelly, A. C., et al. (2020). Chronically elevated norepinephrine concentrations lower glucose uptake in fetal sheep. Am. J. Physiol. Regul. Integr. Comp. Physiol. 319, R255-R263. doi: 10.1152/ajpregu.00365.2019

Davis, M. A., Camacho, L. E., Pendleton, A. L., Antolic, A. T., Luna-Ramirez, R. I., Kelly, A. C., et al. (2021). Augmented glucose production is not contingent on high catecholamines in fetal sheep with IUGR. J. Endocrinol. 249, 195-207. doi: 10.1530/JOE-21-0071

Davis, T. A., and Fiorotto, M. L. (2009). Regulation of muscle growth in neonates. Curr. Opin. Clin. Nutr. Metab. Care 12, 78-85. doi: 10.1097/MCO.0b013e32831cef9f

Desai, M., Gayle, D. A., Casillas, E., Boles, J., and Ross, M. G. (2009). Early undernutrition attenuates the inflammatory response in adult rat offspring. $J$. Matern. Fetal Neonatal Med. 22, 571-575. doi: 10.1080/14767050902874105 
Dinarello, C. A. (2000). Interleukin-18, a proinflammatory cytokine. Eur. Cytokine Netw. 11, 483-486. doi: 10.1684/ecn.2006.0047

Dwyer, C. M., Conington, J., Corbiere, F., Holmoy, I. H., Muri, K., Nowak, R., et al. (2016). Invited review: improving neonatal survival in small ruminants: science into practice. Animal 10, 449-459. doi: 10.1017/S1751731115001974

Dyck, D. J., Heigenhauser, G. J., and Bruce, C. R. (2006). The role of adipokines as regulators of skeletal muscle fatty acid metabolism and insulin sensitivity. Acta Physiol. (Oxf). 186, 5-16. doi: 10.1111/j.1748-1716.2005.01502.x

Edwards, A. K., McKnight, S. M., Askelson, K., McKnight, J. R., Dunlap, K. A., and Satterfield, M. C. (2020). Adaptive responses to maternal nutrient restriction alter placental transport in ewes. Placenta 96, 1-9. doi: 10.1016/j.placenta.2020.05.002

Eifert, A. W., Wilson, M. E., Vonnahme, K. A., Camacho, L. E., Borowicz, P. P., Redmer, D. A., et al. (2015). Effect of melatonin or maternal nutrient restriction on vascularity and cell proliferation in the ovine placenta. Anim. Reprod. Sci. 153, 13-21. doi: 10.1016/j.anireprosci.2014.11.022

Flinn, T., Kleemann, D. O., Swinbourne, A. M., Kelly, J. M., Weaver, A. C., Walker, S. K., et al. (2020). Neonatal lamb mortality: major risk factors and the potential ameliorative role of melatonin. J. Anim. Sci. Biotechnol. 11, 107. doi: 10.1186/s40104-020-00510-w

Gagnon, R. (2003). Placental insufficiency and its consequences. Eur. J. Obstet. Gynecol. Reprod. Biol. 110(Suppl 1), S99-S107. doi: 10.1016/S0301-2115(03)00179-9

Gao, F., Ni, Y., Luo, Z., Liang, Y., Yan, Z., Xu, X., et al. (2012). Atorvastatin attenuates TNF- $\alpha$-induced increase of glucose oxidation through PGC- $1 \alpha$ upregulation in cardiomyocytes. J. Cardiovasc. Pharmacol. 59, 500-506. doi: 10.1097/FJC.0b013e31824c853c

Gibbs, R. L., Swanson, R. M., Beard, J. K., Schmidt, T. B., Petersen, J. L., and Yates, D. T. (2020). Deficits in growth, muscle mass, and body composition following placental insufficiency-induced intrauterine growth restriction persisted in lambs at $60 \mathrm{~d}$ of age but were improved by daily clenbuterol supplementation. Transl. Anim. Sci. 4(Suppl 1), S53-S57. doi: 10.1093/tas/txaa097

Gibbs, R. L., Swanson, R. M., Beard, J. K., Schmidt, T. B., Petersen, J. L., and Yates, D. T. (2021). Deficits in skeletal muscle glucose metabolism and whole-body oxidative metabolism in the IUGR juvenile lamb are improved by daily treatment with clenbuterol. Transl. Anim. Sci. 5(4 Suppl 1). doi: $10.1093 /$ tas/txab187

Greenwood, P., Cafe, L., Hearnshaw, H., and Hennessy, D. (2005). Consequences of nutrition and growth retardation early in life for growth and composition of cattle and eating quality of beef. Recent Adv. Anim. Nutr. Austr. 15, 183-195.

Greenwood, P. L., and Bell, A. W. (2003). Consequences of intra-uterine growth retardation for postnatal growth, metabolism and pathophysiology. Reprod. Suppl. 61, 195-206.

Greenwood, P. L., and Bell, A. W. (2019). Developmental programming and growth of livestock tissues for meat production. Vet. Clin. North Am. Food Anim. Pract. 35, 303-319. doi: 10.1016/j.cvfa.2019.02.008

Greenwood, P. L., and Cafe, L. M. (2007). Prenatal and pre-weaning growth and nutrition of cattle: long-term consequences for beef production. Animal 1, 1283-1296. doi: 10.1017/S175173110700050X

Greenwood, P. L., Hunt, A. S., Hermanson, J. W., and Bell, A. W. (2000). Effects of birth weight and postnatal nutrition on neonatal sheep: II. Skeletal muscle growth and development. J. Anim. Sci. 78, 50-61. doi: 10.2527/2000.78150x

Guo, R., Hou, W., Dong, Y., Yu, Z., Stites, J., and Weiner, C. P. (2010). Brain injury caused by chronic fetal hypoxemia is mediated by inflammatory cascade activation. Reprod. Sci. 17, 540-548. doi: 10.1177/1933719110364061

Haddad, F., Zaldivar, F., Cooper, D. M., and Adams, G. R. (2005). IL-6induced skeletal muscle atrophy. J. Appl. Physiol. (1985). 98, 911-917. doi: 10.1152/japplphysiol.01026.2004

Hales, C. N., and Barker, D. J. (1992). Type 2 (non-insulin-dependent) diabetes mellitus: the thrifty phenotype hypothesis. Diabetologia 35, 595-601. doi: $10.1007 /$ BF00400248

Hales, C. N., Barker, D. J., Clark, P. M., Cox, L. J., Fall, C., Osmond, C., et al. (1991). Fetal and infant growth and impaired glucose tolerance at age 64. BMJ. 303, 1019-1022. doi: 10.1136/bmj.303.6809.1019

Harms, R. Z., Yarde, D. N., Guinn, Z., Lorenzo-Arteaga, K. M., Corley, K. P., Cabrera, M. S., et al. (2015). Increased expression of IL-18 in the serum and islets of type 1 diabetics. Mol. Immunol. 64, 306-312. doi: 10.1016/j.molimm.2014.12.012
Hudalla, H., Karenberg, K., Kuon, R. J., Pöschl, J., Tschada, R., and Frommhold, D. (2018). LPS-induced maternal inflammation promotes fetal leukocyte recruitment and prenatal organ infiltration in mice. Pediatr. Res. 84, 757-764. doi: 10.1038/s41390-018-0030-z

Jensen, C. B., Storgaard, H., Dela, F., Holst, J. J., Madsbad, S., and Vaag, A. A. (2002). Early differential defects of insulin secretion and action in 19year-old caucasian men who had low birth weight. Diabetes 51, 1271-1280. doi: 10.2337/diabetes.51.4.1271

Ji, Y., Wu, Z., Dai, Z., Wang, X., Li, J., Wang, B., et al. (2017). Fetal and neonatal programming of postnatal growth and feed efficiency in swine. J. Anim. Sci. Biotechnol. 8, 42. doi: 10.1186/s40104-017-0173-5

Johansson, A., Lau, J., Sandberg, M., Borg, L. A., Magnusson, P. U., and Carlsson, P. O. (2009). Endothelial cell signalling supports pancreatic beta cell function in the rat. Diabetologia 52, 2385-2394. doi: 10.1007/s00125-009-1485-6

Johnson, D. E., O'Keefe, R. A., and Grandis, J. R. (2018). Targeting the IL6/JAK/STAT3 signalling axis in cancer. Nat. Rev. Clin. Oncol. 15, 234-248. doi: $10.1038 /$ nrclinonc. 2018.8

Kelly, A. C., Bidwell, C. A., McCarthy, F. M., Taska, D. J., Anderson, M. J. Camacho, L. E., et al. (2017). RNA sequencing exposes adaptive and immune responses to intrauterine growth restriction in fetal sheep islets. Endocrinology 158, 743-755. doi: 10.1210/en.2016-1901

Kemp, M. W. (2014). Preterm birth, intrauterine infection, and fetal inflammation. Front. Immunol. 5, 574. doi: 10.3389/fimmu.2014.00574

Kesavan, K., and Devaskar, S. U. (2019). Intrauterine growth restriction: postnatal monitoring and outcomes. Pediatr. Clin. North Am. 66, 403-423. doi: 10.1016/j.pcl.2018.12.009

Kirchofer, K. S., Calkins, C. B., and Gwartney, B. L. (2002). Fiber-type composition of muscles of the beef chuck and round. J. Anim. Sci. 80, 2872-2878. doi: $10.2527 / 2002.80112872 x$

Knudsen, J. G., Gudiksen, A., Bertholdt, L., Overby, P., Villesen, I., Schwartz, C. L., et al. (2017). Skeletal muscle IL-6 regulates muscle substrate utilization and adipose tissue metabolism during recovery from an acute bout of exercise. PLoS ONE 12, e0189301. doi: 10.1371/journal.pone.0189301

Krajewski, P., Sieroszewski, P., Karowicz-Bilinska, A., Kmiecik, M., Chudzik, A., Strzalko-Gloskowska, B., et al. (2014). Assessment of interleukin-6, interleukin8 and interleukin-18 count in the serum of IUGR newborns. J. Matern. Fetal Neonatal Med. 27, 1142-1145. doi: 10.3109/14767058.2013.851186

Kubota, T., Kubota, N., Kumagai, H., Yamaguchi, S., Kozono, H., Takahashi, T., et al. (2011). Impaired insulin signaling in endothelial cells reduces insulin-induced glucose uptake by skeletal muscle. Cell Metab. 13, 294-307. doi: 10.1016/j.cmet.2011.01.018

Lacey, T. A., Gibbs, R. L., Most, M. S., Beer, H. N., Hicks, Z. H., Grijalva, P. C., Petersen, J. L., and Yates, D. T. (2021). Decreased fetal biometrics and impaired $\beta$ cell function in IUGR fetal sheep are improved by daily $\omega-3$ PUFA infusion. Transl. Anim. Sci. 5(4 Suppl 1). doi: 10.1093/tas/txab168

Lackman, F., Capewell, V., Gagnon, R., and Richardson, B. (2001). Fetal umbilical cord oxygen values and birth to placental weight ratio in relation to size at birth. Am. J. Obstet. Gynecol. 185, 674-682. doi: 10.1067/mob.2001.1 16686

Lang, C. H., Frost, R. A., Nairn, A. C., MacLean, D. A., and Vary, T. C. (2002), TNF-alpha impairs heart and skeletal muscle protein synthesis by altering translation initiation. Am. J. Physiol. Endocrinol. Metab. 282, E336-E347. doi: 10.1152/ajpendo.00366.2001

Lemley, C. O., Meyer, A. M., Camacho, L. E., Neville, T. L., Newman, D. J., Caton, J. S., et al. (2012). Melatonin supplementation alters uteroplacental hemodynamics and fetal development in an ovine model of intrauterine growth restriction. Am. J. Physiol. Regul. Integr. Comp. Physiol. 302, R454-R467. doi: 10.1152/ajpregu.00407.2011

Li, W., Moylan, J. S., Chambers, M. A., Smith, J., and Reid, M. B. (2009). Interleukin-1 stimulates catabolism in $\mathrm{C} 2 \mathrm{C} 12$ myotubes. Am. J. Physiol. Cell Physiol. 297, C706-C714. doi: 10.1152/ajpcell.00626.2008

Li, Y. P., and Reid, M. B. (2001). Effect of tumor necrosis factor-alpha on skeletal muscle metabolism. Curr. Opin. Rheumatol. 13, 483-487. doi: 10.1097/00002281-200111000-00005

Limesand, S. W., Jensen, J., Hutton, J., and Hay, W. W. Jr. (2005). Diminished beta-cell replication contributes to reduced beta-cell mass in fetal sheep with intrauterine growth restriction. Am. J. Physiol. Regul. Integr. Comp. Physiol. 288, R1297-R305. doi: 10.1152/ajpregu.00494.2004 
Limesand, S. W., and Rozance, P. J. (2017). Fetal adaptations in insulin secretion result from high catecholamines during placental insufficiency. J. Physiol. 595, 5103-5113. doi: 10.1113/JP273324

Limesand, S. W., Rozance, P. J., Smith, D., and Hay, W. W. Jr. (2007). Increased insulin sensitivity and maintenance of glucose utilization rates in fetal sheep with placental insufficiency and intrauterine growth restriction. Am. J. Physiol. Endocrinol. Metab. 293, E1716-E1725. doi: 10.1152/ajpendo.00459.2007

Limesand, S. W., Rozance, P. J., Zerbe, G. O., Hutton, J. C., and Hay, W. W. Jr. (2006). Attenuated insulin release and storage in fetal sheep pancreatic islets with intrauterine growth restriction. Endocrinology 147, 1488-1497. doi: 10.1210/en.2005-0900

Liu, J., and He, J. (2014). Effects of birth weight and postnatal high-fat diet on growth performance, carcass and meat quality in pigs. J. Anim. Plant Sci. 24, 1606-1612.

Lo, J., Bernstein, L. E., Canavan, B., Torriani, M., Jackson, M. B., Ahima, R. S., et al. (2007). Effects of TNF-alpha neutralization on adipocytokines and skeletal muscle adiposity in the metabolic syndrome. Am. J. Physiol. Endocrinol. Metab. 293, E102-E109. doi: 10.1152/ajpendo.00089.2007

Macko, A. R., Yates, D. T., Chen, X., Shelton, L. A., Kelly, A. C., Davis, M. A., et al. (2016). Adrenal demedullation and oxygen supplementation independently increase glucose-stimulated insulin concentrations in fetal sheep with intrauterine growth restriction. Endocrinology 157, 2104-2115. doi: $10.1210 /$ en.2015-1850

Maier, A., McEwan, J. C., Dodds, K. G., Fischman, D. A., Fitzsimons, R. B., and Harris, A. J. (1992). Myosin heavy chain composition of single fibres and their origins and distribution in developing fascicles of sheep tibialis cranialis muscles. J. Musc. Res. Cell Mobil. 13, 551-572. doi: 10.1007/BF017 37997

Makikallio, K., Kaukola, T., Tuimala, J., S. F. K., Hallman, M., and Ojaniemi, M. (2012). Umbilical artery chemokine CCL16 is associated with preterm preeclampsia and fetal growth restriction. Cytokine 60, 377-384. doi: $10.1016 /$ j.cyto.2012.07.008

Matyba, P., Florowski, T., Dasiewicz, K., Ferenc, K., Olszewski, J., Trela, M., et al. (2021). Performance and meat quality of intrauterine growth restricted pigs. Animals 11, 254. doi: 10.3390/ani11020254

Mericq, V., Ong, K. K., Bazaes, R., Pena, V., Avila, A., Salazar, T., et al. (2005). Longitudinal changes in insulin sensitivity and secretion from birth to age three years in small- and appropriate-for-gestational-age children. Diabetologia 48, 2609-2614. doi: 10.1007/s00125-005-0036-z

Morrison, J. L. (2008). Sheep models of intrauterine growth restriction: fetal adaptations and consequences. Clin. Exp. Pharmacol. Physiol. 35, 730-743. doi: 10.1111/j.1440-1681.2008.04975.x

Nardozza, L. M., Caetano, A. C., Zamarian, A. C., Mazzola, J. B., Silva, C. P., Marcal, V. M., et al. (2017). Fetal growth restriction: current knowledge. Arch. Gynecol. Obstet. 295, 1061-1077. doi: 10.1007/s00404-017-4341-9

Nawabi, M. D., Block, K. P., Chakrabarti, M. C., and Buse, M. G. (1990). Administration of endotoxin, tumor necrosis factor, or interleukin 1 to rats activates skeletal muscle branched-chain alpha-keto acid dehydrogenase. J. Clin. Invest. 85, 256-263. doi: 10.1172/JCI114421

Neel, J. V. (1962). Diabetes mellitus: a "thrifty" genotype rendered detrimental by "progress"? Am. J. Hum. Genet. 14, 353-362.

Niu, Y., He, J., Ahmad, H., Shen, M., Zhao, Y., Gan, Z., et al. (2019a). Dietary curcumin supplementation increases antioxidant capacity, upregulates Nrf2 and Hmoxl levels in the liver of piglet model with intrauterine growth retardation. Nutrients 11, 2978. doi: 10.3390/nu11122978

Niu, Y., He, J., Ahmad, H., Wang, C., Zhong, X., Zhang, L., et al. (2019b). Curcumin attenuates insulin resistance and hepatic lipid accumulation in a rat model of intra-uterine growth restriction through insulin signalling pathway and sterol regulatory element binding proteins. Br. J. Nutr. 122, 616-624. doi: $10.1017 /$ S0007114519001508

Niu, Y., He, J., Zhao, Y., Shen, M., Zhang, L., Zhong, X., et al. (2019c). Effect of curcumin on growth performance, inflammation, insulin level, and lipid metabolism in weaned piglets with IUGR. Animals (Basel) 9, 1098. doi: 10.3390/ani9121098

Oh, J. W., Park, C. W., Moon, K. C., Park, J. S., and Jun, J. K. (2019). The relationship among the progression of inflammation in umbilical cord, fetal inflammatory response, early-onset neonatal sepsis, and chorioamnionitis. PLoS ONE 14, e0225328. doi: 10.1371/journal.pone.0225328
Oleson, B., McGraw, J., Broniowska, K., Annamalai, M., Chen, J., Bushkofsky, J., et al. (2015). Distinct differences in the responses of the human pancreatic $\beta$-cell line EndoC- $\beta \mathrm{H} 1$ and human islets to proinflammatory cytokines. Amer. J. Physiol. Regul. Integr. Comp. Physiol. 309, R525-R534. doi: 10.1152/ajpregu.00544.2014

Oliveira, V., Silva Junior, S. D., de Carvalho, M. H., Akamine, E. H., Michelini, L. C., and Franco, M. C. (2017). Intrauterine growth restriction increases circulating mitochondrial DNA and Toll-like receptor 9 expression in adult offspring: could aerobic training counteract these adaptations? J. Dev. Orig. Health Dis. 8, 236-243. doi: 10.1017/S2040174416000714

Ong, K. K., Petry, C. J., Emmett, P. M., Sandhu, M. S., Kiess, W., Hales, C. N., et al. (2004). Insulin sensitivity and secretion in normal children related to size at birth, postnatal growth, and plasma insulin-like growth factor-I levels. Diabetologia 47, 1064-1070. doi: 10.1007/s00125-004-1405-8

Otis, J. S., Niccoli, S., Hawdon, N., Sarvas, J. L., Frye, M. A., Chicco, A. J., et al. (2014). Pro-inflammatory mediation of myoblast proliferation. PLoS ONE 9, e92363. doi: 10.1371/journal.pone.0092363

Pantham, P., Rosario, F. J., Weintraub, S. T., Nathanielsz, P. W., Powell, T. L., Li, C., et al. (2016). Down-regulation of placental transport of amino acids precedes the development of intrauterine growth restriction in maternal nutrient restricted baboons. Biol. Reprod. 95, 98. doi: 10.1095/biolreprod.116.141085

Pendleton, A. L., Antolic, A. T., Kelly, A. C., Davis, M. A., Camacho, L. E., Doubleday, K., et al. (2020). Lower oxygen consumption and complex I activity in mitochondria isolated from skeletal muscle of fetal sheep with intrauterine growth restriction. Am. J. Physiol. Endocrinol. Metab. 319, E67E80. doi: 10.1152/ajpendo.00057.2020

Pendleton, A. L., Humphreys, L. R., Davis, M. A., Camacho, L. E., Anderson, M. J., and Limesand, S. W. (2019). Increased pyruvate dehydrogenase activity in skeletal muscle of growth-restricted ovine fetuses. Am. J. Physiol. Regul. Integr. Comp. Physiol. 317, R513-r20. doi: 10.1152/ajpregu.00106.2019

Pendleton, A. L., Wesolowski, S. R., Regnault, T. R. H., Lynch, R. M., and Limesand, S. W. (2021). Dimming the powerhouse: mitochondrial dysfunction in the liver and skeletal muscle of intrauterine growth restricted fetuses. Front. Endocrinol. 12, 612888. doi: 10.3389/fendo.2021.612888

Plomgaard, P., Penkowa, M., and Pedersen, B. K. (2005). Fiber type specific expression of TNF-alpha, IL-6 and IL-18 in human skeletal muscles. Exerc. Immunol. Rev. 11, 53-63.

Popa, C., Netea, M. G., van Riel, P. L., van der Meer, J. W., and Stalenhoef, A. F. (2007). The role of TNF-alpha in chronic inflammatory conditions, intermediary metabolism, and cardiovascular risk. J. Lipid Res. 48, 751-762. doi: 10.1194/jlr.R600021-JLR200

Posont, R., Beede, K., Limesand, S., and Yates, D. (2018). Changes in myoblast responsiveness to TNFa and IL- 6 contribute to decreased skeletal muscle mass in intrauterine growth restricted fetal sheep. Transl. Anim. Sci. 2(Suppl 1), S44-S47. doi: 10.1093/tas/txy038

Posont, R. J. (2019). The Role of Inflammatory Pathways in Development, Growth, and Metabolism of Skeletal Muscle in IUGR Offspring; Blood Gene Expression of Inflammatory Factors as Novel Biomarkers for Assessing Stress and Wellbeing in Exotic Species. MS Thesis, Department of Animal Science, University of Nebraska-Lincoln.

Posont, R. J., Cadaret, C. N., Barnes, T. L., and Yates, D. T. (2017). A potential role for mTORC1/2 in $\beta 2$ adrenergic regulation of skeletal muscle glucose oxidation in models of intrauterine growth restriction. Diabesity 3, 9-12. doi: 10.15562/diabesity.2017.40

Posont, R. J., Cadaret, C. N., Beard, J. K., Swanson, R. M., Gibbs, R. L., MarksNelson, E. S., et al. (2021). Maternofetal inflammation induced for $2 \mathrm{wk}$ in late gestation reduced birth weight and impaired neonatal growth and skeletal muscle glucose metabolism in lambs. J. Anim. Sci. 99, skab102. doi: 10.1093/jas/skab102

Posont, R. J., and Yates, D. T. (2019). Postnatal nutrient repartitioning due to adaptive developmental programming. Vet. Clin. North Am. Food Anim. Pract. 35, 277-288. doi: 10.1016/j.cvfa.2019.02.001

Poudel, R., McMillen, I. C., Dunn, S. L., Zhang, S., and Morrison, J. L. (2015). Impact of chronic hypoxemia on blood flow to the brain, heart, and adrenal gland in the late-gestation IUGR sheep fetus. Am. J. Physiol. Regul. Integr. Comp. Physiol. 308, R151-R162. doi: 10.1152/ajpregu.00036.2014

Raychaudhuri, N., Raychaudhuri, S., Thamotharan, M., and Devaskar, S. U. (2008). Histone code modifications repress glucose transporter 4 expression in 
the intrauterine growth-restricted offspring. J. Biol. Chem. 283, 13611-13626. doi: 10.1074/jbc.M800128200

Regnault, T. R., de Vrijer, B., Galan, H. L., Davidsen, M. L., Trembler, K. A., Battaglia, F. C., et al. (2003). The relationship between transplacental $\mathrm{O}_{2}$ diffusion and placental expression of PIGF, VEGF and their receptors in a placental insufficiency model of fetal growth restriction. J. Physiol. 550, 641-656. doi: 10.1113/jphysiol.2003.039511

Regnault, T. R., Friedman, J. E., Wilkening, R. B., Anthony, R. V., and Hay, W. W. Jr. (2005). Fetoplacental transport and utilization of amino acids in IUGR-a review. Placenta 26(Suppl A), S52-S62. doi: 10.1016/j.placenta.2005. 01.003

Reid, M. B., and Li, Y. P. (2001). Cytokines and oxidative signalling in skeletal muscle. Acta Physiol. Scand. 171, 225-232. doi: 10.1046/j.1365-201x.2001.00824.x

Remels, A. H., Gosker, H. R., Verhees, K. J., Langen, R. C., and Schols, A. M. (2015). TNF-alpha-induced NF-kappaB activation stimulates skeletal muscle glycolytic metabolism through activation of HIF-1alpha. Endocrinology 156, 1770-1781. doi: 10.1210/en.2014-1591

Reynolds, L. P., Borowicz, P. P., Caton, J. S., Crouse, M. S., Dahlen, C. R., and Ward, A. K. (2019). Developmental programming of fetal growth and development. Vet. Clin. North Am. Food Anim. Pract. 35, 229-247. doi: 10.1016/j.cvfa.2019.02.006

Reynolds, L. P., Borowicz, P. P., Caton, J. S., Vonnahme, K. A., Luther, J. S., Hammer, C. J., et al. (2010). Developmental programming: the concept, large animal models, and the key role of uteroplacental vascular development. J. Anim. Sci. 88(13 Suppl), E61-E72. doi: 10.2527/jas.2009-2359

Rhoades, R. D., King, D. A., Jenschke, B. E., Behrends, J. M., Hively, T. S., and Smith, S. B. (2005). Postmortem regulation of glycolysis by 6phosphofructokinase in bovine M. Sternocephalicus pars mandibularis. Meat. Sci. 70, 621-626. doi: 10.1016/j.meatsci.2005.01.024

Riddle, E. S., Campbell, M. S., Lang, B. Y., Bierer, R., Wang, Y., Bagley, H. N., et al. (2014). Intrauterine growth restriction increases TNF alpha and activates the unfolded protein response in male rat pups. J. Obes. 2014, 829862. doi: $10.1155 / 2014 / 829862$

Roberge, S., Nicolaides, K., Demers, S., Hyett, J., Chaillet, N., and Bujold, E. (2017). The role of aspirin dose on the prevention of preeclampsia and fetal growth restriction: systematic review and meta-analysis. Am. J. Obstet. Gynecol. 216, 110.e6-120.e6. doi: 10.1016/j.ajog.2016.09.076

Robinson, D. L., Cafe, L. M., and Greenwood, P. L. (2013). Meat Science and Muscle Biology Symposium: developmental programming in cattle: consequences for growth, efficiency, carcass, muscle, and beef quality characteristics. J. Anim. Sci. 91, 1428-1442. doi: 10.2527/jas.201 2-5799

Romero, R., Gotsch, F., Pineles, B., and Kusanovic, J. P. (2007). Inflammation in pregnancy: its roles in reproductive physiology, obstetrical complications, and fetal injury. Nutr. Rev. 65(12 Pt 2), S194-S202. doi: 10.1301/nr.2007.dec.S194-S202

Rozance, P. J., Anderson, M., Martinez, M., Fahy, A., Macko, A. R., Kailey, J., et al. (2015). Placental insufficiency decreases pancreatic vascularity and disrupts hepatocyte growth factor signaling in the pancreatic islet endothelial cell in fetal sheep. Diabetes 64, 555-564. doi: 10.2337/db14-0462

Rozance, P. J., Zastoupil, L., Wesolowski, S. R., Goldstrohm, D. A., Strahan, B., Cree-Green, M., et al. (2018). Skeletal muscle protein accretion rates and hindlimb growth are reduced in late gestation intrauterine growth-restricted fetal sheep. J. Physiol. 596, 67-82. doi: 10.1113/JP27 5230

Saghizadeh, M., Ong, J. M., Garvey, W. T., Henry, R. R., and Kern, P. A. (1996). The expression of TNF alpha by human muscle. Relationship to insulin resistance. J. Clin. Invest. 97, 1111-1116. doi: 10.1172/JCI118504

Saleem, T., Sajjad, N., Fatima, S., Habib, N., Ali, S., and Qadir, M. (2011). Intrauterine growth retardation - small events, big consequences. Ital. J. Pediatr. 37, 41. doi: 10.1186/1824-7288-37-41

Sedgh, G., Singh, S., and Hussain, R. (2014). Intended and unintended pregnancies worldwide in 2012 and recent trends. Stud. Fam. Plann. 45, 301-314. doi: $10.1111 /$ j.1728-4465.2014.00393.x

Sharma, D., Farahbakhsh, N., Shastri, S., and Sharma, P. (2016a). Intrauterine growth restriction - part 2. J. Matern. Fetal Neonatal Med. 29, 4037-4048. doi: $10.3109 / 14767058.2016 .1154525$
Sharma, D., Sharma, P., and Shastri, S. (2017). Genetic, metabolic and endocrine aspect of intrauterine growth restriction: an update. J. Matern. Fetal Neonatal Med. 30, 2263-2275. doi: 10.1080/14767058.2016.1245285

Sharma, D., Shastri, S., Farahbakhsh, N., and Sharma, P. (2016b). Intrauterine growth restriction - part 1. J. Matern. Fetal Neonatal Med. 29, 3977-3987. doi: 10.3109/14767058.2016.1152249

Soto, N., Bazaes, R. A., Pena, V., Salazar, T., Avila, A., Iniguez, G., et al. (2003). Insulin sensitivity and secretion are related to catch-up growth in small-forgestational-age infants at age 1 year: results from a prospective cohort. J. Clin. Endocrinol. Metab. 88, 3645-3650. doi: 10.1210/jc.2002-030031

Soto, S. M., Blake, A. C., Wesolowski, S. R., Rozance, P. J., Barthel, K. B., Gao, B., et al. (2017). Myoblast replication is reduced in the IUGR fetus despite maintained proliferative capacity in vitro. J. Endocrinol. 232, 475-491. doi: 10.1530/JOE-16-0123

Stremming, J., Jansson, T., Powell, T. L., Rozance, P. J., and Brown, L. D. (2020). Reduced $\mathrm{Na}(+) \mathrm{K}(+)$-ATPase activity may reduce amino acid uptake in intrauterine growth restricted fetal sheep muscle despite unchanged ex vivo amino acid transporter activity. J. Physiol. 598, 1625-1639. doi: 10.1113/JP278933

Sumitani, S., Goya, K., Testa, J. R., Kouhara, H., and Kasayama, S. (2002). Akt1 and Akt2 Differently regulate muscle creatine kinase and myogenin gene transcription in insulin-induced differentiation of C2C12 myoblasts. Endocrinology 143, 820-828. doi: 10.1210/endo.143.3.8687

Sutton, G. M., Centanni, A. V., and Butler, A. A. (2010). Protein malnutrition during pregnancy in C57BL/6J mice results in offspring with altered circadian physiology before obesity. Endocrinology 151, 1570-1580. doi: 10.1210/en.2009-1133

Swanson, R. M., Tait, R. G., Galles, B. M., Duffy, E. M., Schmidt, T. B., Petersen, J. L., et al. (2020). Heat stress-induced deficits in growth, metabolic efficiency, and cardiovascular function coincided with chronic systemic inflammation and hypercatecholaminemia in ractopamine-supplemented feedlot lambs. J. Anim. Sci. 98, skaa168. doi: 10.1093/jas/skaal68

Tarry-Adkins, J. L., Fernandez-Twinn, D. S., Hargreaves, I. P., Neergheen, V., Aiken, C. E., Martin-Gronert, M. S., et al. (2016). Coenzyme Q10 prevents hepatic fibrosis, inflammation, and oxidative stress in a male rat model of poor maternal nutrition and accelerated postnatal growth. Am. J. Clin. Nutr. 103, 579-588. doi: 10.3945/ajcn.115.119834

Thorn, S. R., Regnault, T. R., Brown, L. D., Rozance, P. J., Keng, J., Roper, M., et al. (2009). Intrauterine growth restriction increases fetal hepatic gluconeogenic capacity and reduces messenger ribonucleic acid translation initiation and nutrient sensing in fetal liver and skeletal muscle. Endocrinology 150, 3021-3030. doi: 10.1210/en.2008-1789

Tracey, K. J., and Cerami, A. (1993). Tumor necrosis factor, other cytokines and disease. Annu. Rev. Cell Biol. 9, 317-343. doi: 10.1146/annurev.cb.09.110193.001533

Visentin, S., Lapolla, A., Londero, A. P., Cosma, C., Dalfra, M., Camerin, M., et al. (2014). Adiponectin levels are reduced while markers of systemic inflammation and aortic remodelling are increased in intrauterine growth restricted motherchild couple. Biomed Res. Int. 2014, 401595. doi: 10.1155/2014/401595

Wai, S. G., Rozance, P. J., Wesolowski, S. R., Hay, W. W. Jr., and Brown, L. D. (2018). Prolonged amino acid infusion into intrauterine growth restricted fetal sheep increases leucine oxidation rates. Am. J. Physiol. Endocrinol. Metab. 315, E1143-E1153. doi: 10.1152/ajpendo.00128.2018

Wang, J., Cao, M., Yang, M., Lin, Y., Che, L., Fang, Z., et al. (2016). Intra-uterine undernutrition amplifies age-associated glucose intolerance in pigs via altered DNA methylation at muscle GLUT4 promoter. Br. J. Nutr. 116, 390-401. doi: $10.1017 /$ S0007114516002166

Wang, J., Platt, A., Upmanyu, R., Germer, S., Lei, G., Rabe, C., et al. (2013). IL-6 pathway-driven investigation of response to IL-6 receptor inhibition in rheumatoid arthritis. BMJ Open 3, e003199. doi: 10.1136/bmjopen-2013-003199

Wilson, S. J., McEwan, J. C., Sheard, P. W., and Harris, A. J. (1992). Early stages of myogenesis in a large mammal: formation of successive generations of myotubes in sheep tibialis cranialis muscle. J. Musc. Res. Cell Mobil. 13, 534-550. doi: 10.1007/BF01737996

Wolsk, E., Mygind, H., Grøndahl, T. S., Pedersen, B. K., and van Hall, G. (2010). IL6 selectively stimulates fat metabolism in human skeletal muscle. Am. J. Physiol. Endocrinol. Metab. 299, E832-E840. doi: 10.1152/ajpendo.00328.2010 
Wu, G., Bazer, F., Wallace, J., and Spencer, T. (2006). Board-invited review: intrauterine growth retardation: implications for the animal sciences. J. Anim. Sci. 84, 2316-2337. doi: 10.2527/jas.2006-156

Xing, Y., Wei, H., Xiao, X., Chen, Z., Liu, H., Tong, X., et al. (2020). Methylated Vnnl at promoter regions induces asthma occurrence via the PI3K/Akt/NFKB-mediated inflammation in IUGR mice. Biol. Open 9, bio049106. doi: 10.1242/bio.049106

Yates, D. T., Cadaret, C. N., Beede, K. A., Riley, H. E., Macko, A. R., Anderson, M. J., et al. (2016). Intrauterine growth-restricted sheep fetuses exhibit smaller hindlimb muscle fibers and lower proportions of insulin-sensitive Type I fibers near term. Am. J. Physiol. Regul. Integr. Comp. Physiol. 310, R1020-R1029. doi: 10.1152/ajpregu.00528.2015

Yates, D. T., Camacho, L. E., Kelly, A. C., Steyn, L. V., Davis, M. A., Antolic, A. T., et al. (2019). Postnatal beta2 adrenergic treatment improves insulin sensitivity in lambs with IUGR but not persistent defects in pancreatic islets or skeletal muscle. J. Physiol. 597, 5835-5858. doi: 10.1113/JP278726

Yates, D. T., Clarke, D. S., Macko, A. R., Anderson, M. J., Shelton, L. A., Nearing, M., et al. (2014). Myoblasts from intrauterine growthrestricted sheep fetuses exhibit intrinsic deficiencies in proliferation that contribute to smaller semitendinosus myofibres. J. Physiol. 592, 3113-3125. doi: 10.1113/jphysiol.2014.272591

Yates, D. T., Macko, A. R., Nearing, M., Chen, X., Rhoads, R. P., and Limesand, S. W. (2012). Developmental programming in response to intrauterine growth restriction impairs myoblast function and skeletal muscle metabolism. J. Pregnancy 2012, 631038. doi: 10.1155/2012/631038

Yates, D. T., Petersen, J. L., Schmidt, T. B., Cadaret, C. N., Barnes, T. L., Posont, R. J., et al. (2018). ASAS-SSR triennnial reproduction symposium: looking back and moving forward-how reproductive physiology has evolved: fetal origins of impaired muscle growth and metabolic dysfunction: lessons from the heat-stressed pregnant ewe. J. Anim. Sci. 96, 2987-3002. doi: 10.1093/jas/ sky164
Yin, H., Price, F., and Rudnicki, M. A. (2013). Satellite cells and the muscle stem cell niche. Physiol. Rev. 93, 23-67. doi: 10.1152/physrev.00043.2011

Youd, J. M., Rattigan, S., and Clark, M. G. (2000). Acute impairment of insulinmediated capillary recruitment and glucose uptake in rat skeletal muscle in vivo by TNF-alpha. Diabetes 49, 1904-1909. doi: 10.2337/diabetes.49.11.1904

Zhao, M., Chen, Y. H., Dong, X. T., Zhou, J., Chen, X., Wang, H., et al. (2013). Folic acid protects against lipopolysaccharide-induced preterm delivery and intrauterine growth restriction through its anti-inflammatory effect in mice. PLoS ONE 8, e82713. doi: 10.1371/journal.pone.0082713

Author Disclaimer: The contents of this publication are the sole responsibility of the authors and do not necessarily represent the official views of the NIH or NIGMS.

Conflict of Interest: The authors declare that the research was conducted in the absence of any commercial or financial relationships that could be construed as a potential conflict of interest.

Publisher's Note: All claims expressed in this article are solely those of the authors and do not necessarily represent those of their affiliated organizations, or those of the publisher, the editors and the reviewers. Any product that may be evaluated in this article, or claim that may be made by its manufacturer, is not guaranteed or endorsed by the publisher.

Copyright (c) 2021 Hicks and Yates. This is an open-access article distributed under the terms of the Creative Commons Attribution License (CC BY). The use, distribution or reproduction in other forums is permitted, provided the original author(s) and the copyright owner(s) are credited and that the original publication in this journal is cited, in accordance with accepted academic practice. No use, distribution or reproduction is permitted which does not comply with these terms. 